\title{
Karolina Matuszewska*
}

\section{Nostalgia z ducha zabawy. O teatrze Rimasa Tuminasa}

DOI: http://dx.doi.org/10.12775/LC.2018.021

\begin{abstract}
Streszczenie: Twórczość teatralna Rimasa Tuminasa jest jedną z bardziej oryginalnych propozycji scenicznych w litewskim teatrze drugiej połowy XX wieku. Wykształcony w Moskwie reżyser pracował przede wszystkim w Akademickim Teatrze Dramatycznym w Wilnie, z którym był związany aż do założenia w 1990 roku własnego Teatru Małego. Reżyserował także za granicą, zdobywając międzynarodowy rozgłos, m.in. dzięki prezentacjom na Międzynarodowym Festiwalu Teatralnym „Kontakt”. Jego teatr wyrasta z uczucia żalu i tęsknoty za czymś utraconym. Delikatna ironia, posługiwanie się regułami zabawy oraz tworzenie lirycznej, nieco tajemniczej atmosfery spektaklu wyznaczają najbardziej charakterystyczne cechy jego teatru. W centrum zainteresowania Tuminasa znajdują się zwykły człowiek i jego codzienne troski, co zdecydowanie przeciwstawiało się patosowi i heroizmowi popularnych na Litwie w czasach radzieckich dramatów historycznych. Poza odnowieniem repertuaru litewski twórca przyczynił się także do zmian w technice gry aktorskiej: zaproponował swojemu zespołowi nowe poszukiwania twórcze, dzięki którym artyści mogli wyzwolić się ze starych schematów.
\end{abstract}

Słowa kluczowe: Rimas Tuminas, Teatr Mały w Wilnie, nostalgia, zabawa, podróż

\section{Nostalgia with the spirit of play. The theatre of Rimas Tuminas}

\begin{abstract}
The theatrical work of Rimas Tuminas is one of the most original stage concepts in the Lithuanian theatre of the second half of the 20th century. Educated in Moscow, he worked primarily at the Academic Dramatic Theatre in Vilnius, where he stayed until founding his own Small Theatre of Vilnius in 1990. He also directed many performances abroad, gaining international fame, among others thanks to the presentations at the International Theatre Festival "Kontakt". His theatre grows
\end{abstract}

\footnotetext{
* Doktorantka Wydziału Polonistyki Uniwersytetu Warszawskiego, konsultantka literacka w Teatrze Studio. Zajmuje się teatrem litewskim. E-mail: karo.matuszewska@gmail.com.
} 
out of feelings of regret and longing for something lost. Delicate irony, the use of rules of play and the creation of a lyrical, somewhat mysterious atmosphere of the performance designate the most characteristic features of his theatre. Tuminas' focus is on the ordinary man and his daily worries, which radically opposed to the pathos and heroism of historical dramas which were very popular in Lithuania in the Soviet times. Apart from renewing the repertoire, the Lithuanian director also contributed to the changes in acting techniques: he proposed to his team new creative explorations, which enabled artists to liberate themselves from old schemes.

Keywords: Rimas Tuminas, Small Theatre of Vilnius, nostalgia, play, journey

Może nasz „prymitywizm” polega na tym, że staramy się w małej rzeczy, ułamku rzeczywistości zobaczyć cały świat (Tuminas 1998: 12).

$\mathbf{R}$

imas Tuminas powiedział kiedyś, że teatr kojarzy mu się z pięknym sadem. Miał na myśli prostotę i pewnego rodzaju naiwność, która z jednej strony bliska jest pogańskiemu światu dawnej Litwy, z drugiej przenika cały jego teatr. Ten sad to także odwołanie do konkretnego wspomnienia z dzieciństwa, które spędził na prowincji. Urodził się 20 stycznia 1952 roku we wsi koło Kielm (lit. Kelmè) w północno-zachodniej Litwie. Jego ojciec był nauczycielem, który często popadał w konflikt z lokalną władzą, przez co rodzina musiała się nieustannie przeprowadzać. Tuminas wspominał, że w każdym nowym miejscu sadzili drzewa, po czym wyjeżdżali, nie doczekawszy się owoców. Po latach mówił w rozmowie z Ramunè Balevičiūte:

Dzieciństwo kojarzy mi się z ciągłym niepokojem. Szczęścia w nim nie pamiętam. Nie powiedziałbym, że moje dzieciństwo było trudne, ale przeważały w nim niepokój, tęsknota i poczucie, że nieustannie czegoś żal. Idzie jakiś człowiek, a mi jest go żal. Że mieszka tu i nie wie, że istnieje wielki świat, wielkie przestrzenie. I mnie samemu wciąż wydawało się, że muszę być gdzie indziej, bo mojego życia tutaj nie ma. Możliwe, że wpływ na to miały nasze regularne przeprowadzki (Balevičiūtė 2012: 13).

$\mathrm{Z}$ tego uczucia rodzi się cała rzeczywistość teatru Tuminasa. Jego spektakle, pełne twórczych sprzeczności, nieoczywistych rozwiązań formalnych i bogactwa znaczeń, są jednocześnie przesiąknięte atmosferą tęsknoty i żalu za czymś utraconym lub nieosiągalnym, często też nienazwanym. Narracja w nich jest podporządkowana logice snu albo wspomnienia. Nie ma w niej ciągłości, sceny dramatyczne są ze sobą luźno powiązane, często przerywane komiczną pantomimą. Tuminas myśli obrazami, które umieszcza w wyraźnych ramach. Swoje spektakle zaczyna bez pośpiechu. Powolny rytm i często długa, pantomimiczna scena otwarcia pozwalają widzowi spokojnie wejść w teatralną rzeczywistość. W podobny sposób traktuje finały: często zwalnia rytm i zapętla działanie lub buduje coś na kształt filmowej stopklatki - jakby chciał w ten sposób zatrzymać czas i zachować to, co za chwilę zniknie w ciemności. Posąg Niny w Maskaradzie, taniec sióstr Prozorow w Trzech 
siostrach, zarys synagogi w Uśmiechnij się do nas, Panie czy swoisty pomnik romantyzmu w Mistrzu to obrazy upamiętniające przeszłość, do której nie ma już powrotu.

Jako chłopak wychowywany na wsi Tuminas nie miał możliwości zetknięcia się z teatrem. W jego życiu natomiast dosyć wcześnie pojawił się film. Do jego rodzinnej wsi dwa razy w tygodniu przyjeżdżało kino objazdowe, w którym czasem pomagał przewozić taśmy i całą aparaturę. Nic zatem dziwnego, że kiedy po skończeniu szkoły przyjechał do Wilna, zamiast wojska wybrał studia na Wydziale Reżyserii Telewizyjnej w Konserwatorium. Trafił jednak na Wydział Aktorski, ale aktorem zostać nie chciał, więc wyjechał do Moskwy. Tam ukończył studia reżyserii teatralnej na kursie Josifa Tumanowa, znanego głównie z wystawiania oper, operetek i przedstawień masowych. Znacznie większy wpływ na edukację artystyczną Tuminasa miały jednak częste wizyty na Małej Bronnej, gdzie uczestniczył w próbach do spektakli Anatolija Efrosa. Szybko też zaprzyjaźnił się z reżyserem i jego aktorami.

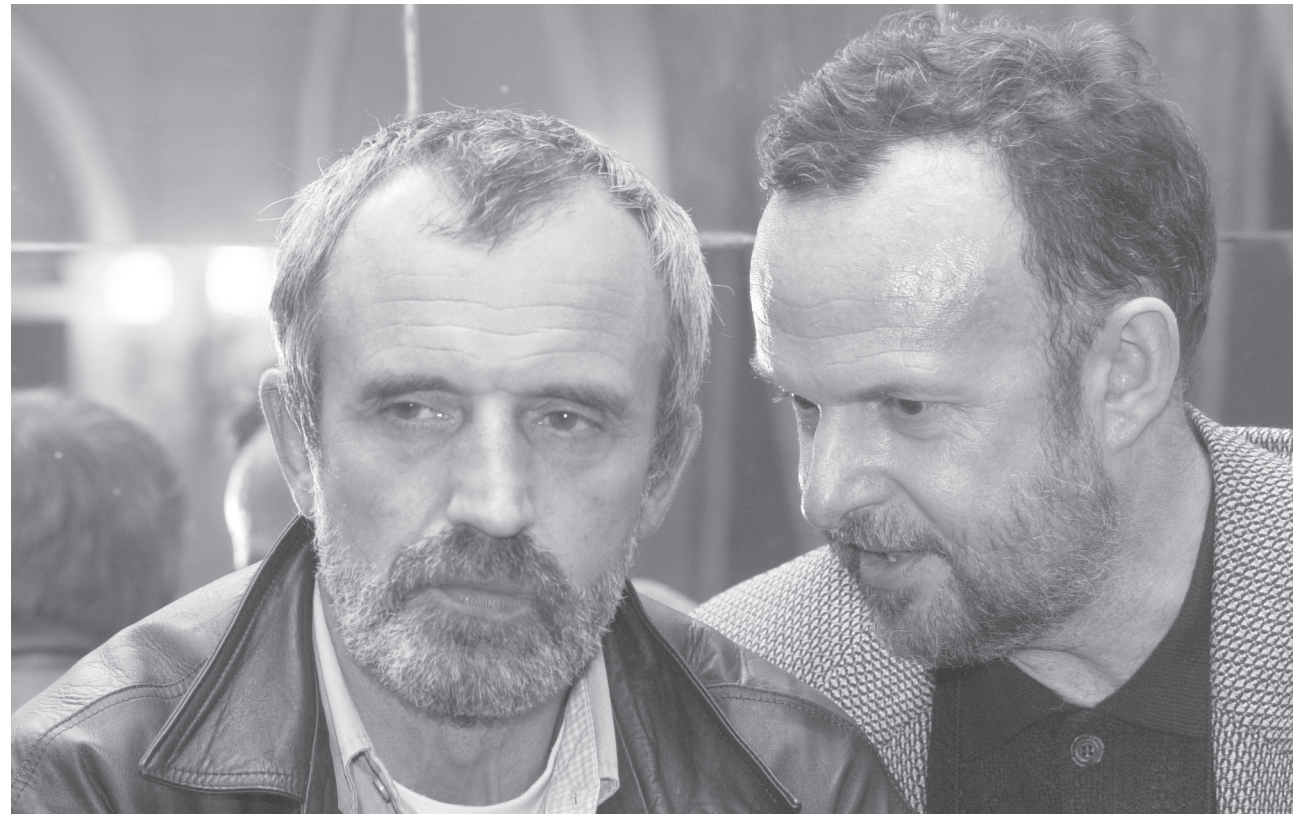

Rimas Tuminas i Rolandas Rastauskas

Fot. Wojtek Szabelski. Z archiwum Teatru im. W. Horzycy

Po ukończeniu studiów w Moskwie wrócił do Wilna, gdzie od razu został etatowym reżyserem Akademickiego Teatru Dramatycznego. Jego ówczesny dyrektor Henrikas Vancevičius, który kierował teatrem od 1966 aż do 1989 roku, zaprosił do współpracy trójkę młodych reżyserów: Algirdasa Lapėnasa (od 1968), Irenę Bučienė (od 1970) oraz nieco później Tuminasa, których obecność miała odświeżyć wileńską scenę. Już pierwsze spektakle tego ostatniego: debiutancki Viduržiemis (Styczeń) współczesnego pisarza bulgarskiego Jordana Radiczkowa (1978) oraz Emigrantas iš Brisbeino (Emigrant z Brisbane) Georges’a Schehadégo (1980) znacząco wyróżniały się na tle repertuaru zdominowanego przez monumentalne, realistyczno-psychologiczne spektakle Vancevičiusa oparte na litewskich dramatach historycznych. Od rozmachu inscenizacyjnego Tuminas wolał kameralność przestrzeni i intymny kontakt zarówno pomiędzy aktorami, jak i - sceną a widownią. 
Prawdopodobnie z tego względu litewska dramaturgia nigdy go specjalnie nie interesowała. W początkowym okresie swojej działalności sięgał głównie po współczesnych autorów radzieckich i wschodnich, rzadziej zachodnich. Wynikało to z jednej strony z nakazów cenzury, z drugiej jednak utwory nowego pokolenia radzieckich autorów znacznie różniły się od wątpliwej jakości dramatów socrealistycznych. Ich bohaterem stawał się zwykły człowiek, samotny i nieszczęśliwy, zmagający się z nudną, nieprzyjazną i pozbawioną perspektyw rzeczywistością. W jego losie Tuminas dostrzegał prawdziwy tragizm, o którym chciał opowiadać w swoich przedstawieniach.

Viduržiemis to symboliczna i pełna aluzji biblijnych opowieść o drwalach mieszkających w bułgarskiej wsi, którzy toczą dziwną walkę z żyjącymi wokół wilkami. Z kolei tytułowy bohater Emigranta $z$ Brisbane przybywa do niewielkiego miasteczka na Sycylii w poszukiwaniu swojego nieślubnego syna, którego chce uczynić spadkobiercą. Chciwość i żądza bogactwa skłaniają część mieszkańców do kłamstw, manipulacji, a nawet, w wypadku kobiet, do poświęcenia własnego honoru i reputacji. W 1982 roku Tuminas wystawil Fẻjos Dražé variacijos (Wariacje wróżki Draże) Andrieja Kuternickiego - „cztery poruszające historie o samotności i tęsknotach mieszkańców pewnego bloku komunalnego. Skupiając się na pracy z aktorem i budowaniu relacji między postaciami, Tuminas wykreował kameralną atmosferę, nastrój, który litewski krytyk Egmontas Jansonas określił jako „prawdziwy, szczery liryzm, impresjonizm” (cyt. za Aleksaitè et al. 2009: 51). Šarūnè Trinkūnaitė pisała, że „reżyser uważnie bada niuanse psychicznych stanów bohaterów, daje wyraz ich niewymuszonej i naturalnej ekspresji, a jednocześnie pozostawia tajemnicę i nie wyjaśnia wszystkiego do końca, okrywając sceniczną akcję bogatą i sugestywną atmosferą" (Trinkūnaitè).

W dużym stopniu efekt ten osiągał dzięki inscenizacji. W Viduržiemis scenografia debiutującego Augisa Kepežinskasa nawiązywała do folklorystycznych i bajkowych obrazów, przedstawiając wnętrze okrytej śniegiem wiejskiej chaty. W Emigrancie z Brisbane jej centralny punkt stanowiła szumiąca fontanna, z której przez cały spektakl dobiegały przyjemne dla ucha sycylijskie melodie. Reżyser nie tyle wiernie odtworzył na scenie całe miasteczko, co raczej wykreował jego atmosferę. Zdaniem Ramune Balevičiūtė „w pierwszych spektaklach Tuminasa złożona i sugestywna atmosfera przekazywała bardzo konkretnie miejsce i ducha czasu, natomiast w Fëjos Dražè variacijos stawała się czymś więcej: ucieleśniała temat spektaklu" (Balevičiūtė 2012: 58). Wkrótce taki sposób kreowania teatralnego świata stał się rozpoznawalnym znakiem Tuminasa. Reżyser nigdy nie należał do twórców szczególnie przywiązanych do literatury - duże partie tekstu często zastępował scenicznymi obrazami. W wywiadzie udzielonym miesięcznikowi „Teatr” mówił:

Odnoszę się do literatury z szacunkiem, jakkolwiek mój stosunek do niej jest skomplikowany. [...] Czasami zdarza się, że podczas pracy nad spektaklem aktorzy mówią mi: „Przecież tego nie ma w tekście”, wówczas denerwuję się i tłumaczę im, że wszystko, co przekształca się w język teatru, jest zapisane w tekście (Tuminas 1998).

Od samego początku Tuminas przykładał szczególną wagę do pracy z aktorami. Zachęcał ich do twórczej, a nie odtwórczej postawy, wyjścia poza realizm psychologiczny, poszukiwań, zabawy i improwizacji. Nic zatem dziwnego, że wokół reżysera dość szybko zaczęła gromadzić się grupa aktorów, którzy chcieli wraz z nim poszukiwać nowych środków wyrazu i scenicznej prawdy. W 1982 roku do zespołu Teatru Akademickiego dołączyli 
absolwenci kursu Tuminasa: Inga Burneikaite, Jūratė Brogaitè, Larisa Kalpokaitė, Arvydas Dapšys, Eglè Čekuolytė, Vilija Ramanauskaitė, Almantas Šinkūnas, Andrius Žebrauskas. Zostawali po godzinach w teatrze, próbując na małej sali, co wzbudzało podejrzenia administracji budynku. „Diabeł wie, czym się zajmują te maluchy!” - mawiano w Akademickim. Aby uniknąć kłopotów, Tuminas wpadł na pomysł przygotowania spektaklu z udziałem doświadczonej aktorki Teatru Akademickiego Moniki Mironaitė. Jej mężem był wówczas deputowany Rady Najwyższej ZSRR Juozas Baltušis, co zapewniło twórcom zgodę na realizację przedstawienia. Tak powstało Tyli naktis (Cicha noc) Harolda Müllera (1984), które zainaugurowało działalność Małej Sceny - pierwszej tego typu na Litwie.

Dla Tuminasa było to drugie, po Fëjos Dražè variacijos, doświadczenie pracy ze znacznie starszymi aktorami. W kameralnym przedstawieniu o wigilijnym spotkaniu syna z matką, którą co roku przywozi na święta z domu opieki, siedemdziesięcioletniej Mironaitè partnerował o dwadzieścia lat młodszy Mykolas Smagarauskas. Jego bohater przez większość przedstawienia milczał, to kobieta mówiła. Tuminas w przejmujący sposób ukazał w tym spektaklu ludzką samotność, potrzebę bliskości z drugim człowiekiem, złudzenia, że jest na świecie ktoś, kto zechce nas wysłuchać. Te tematy powracały zresztą w jego kolejnych przedstawieniach, stając się swego rodzaju lejtmotywem całej twórczości reżysera.

Lata 80. to dla Tuminasa czas poszukiwań własnego języka teatralnego, a także kompletowania zespołu aktorskiego. W tych pierwszych przedstawieniach dało się zauważyć cechy charakterystyczne dla całej późniejszej twórczości reżysera: delikatną ironię, subtelną wibrację nastrojów, posługiwanie się regułami zabawy oraz tworzenie lirycznej, nieco tajemniczej atmosfery spektaklu. Poszczególne elementy, takie jak przestrzeń, światło, muzyka ${ }^{2}$, rytmy wyznaczane przez dramatyczne pauzy oraz naturalna, nieoparta na „przeżywaniu” gra aktorów budowały poruszające, intymne przedstawienia o codzienności ludzi bliskich tym, którzy siedzieli na widowni. Tuminas traktował swoich bohaterów z dużą czułością i pobłażliwością, nie osądzając surowo ich wad ani słabości. W tym duchu realizował kolejne spektakle, m.in. Kotkę na goracym, blaszanym dachu Tennessee Williamsa (1983), Svečiai atvyksta prieš perkūnija, arba Sausainiai su gvazdikèliais (Goście przybywaja przed burza, albo ciasteczka z goździkami) Romualdasa Lankauskasa (1985), dramaty współczesnych radzieckich autorów: Tarytum mes nepažistami (Jakbyśmy się nie znali) Andrieja Kuternickiego (1985) i Ir vèlei tenai, kur marios šviesu (Žana) (Znowu tam, gdzie morze światet (Jeanne)) Aleksandra Galina (1986) oraz Podwójna niestałość Pierre’a de Marivaux (1987). Choć żaden z nich nie powtórzył sukcesu Féjos Dražé variacijos, był to ważny etap na drodze kształtowania idei własnego, intymnego teatru kameralnego, w którym Tuminas mógłby pracować ze swoim zespołem.

Przełom nastąpił w 1988 roku, kiedy to powstał Čia nebus mirties (Śmierci tu nie będzie), spektakl inspirowany życiem i twórczością litewskiego poety Pauliusa Širvysa (19201979). Przedstawienie okrzyknięto „jednym z najgorętszych wydarzeń litewskiego teatru końca lat 80." (Trinkūnaitė), a jednocześnie nieoficjalną pierwszą premierą Teatru Małego, którego powstanie wynikało z potrzeby całkowitego odcięcia się od Teatru Akademickiego ${ }^{3}$.

\footnotetext{
1 Lit. mažiukai - stąd swoją nazwę wziął Teatr Mały Tuminasa. Por. Balevičiūtè 2012: 73.

2 Stałym współpracownikiem Tuminasa jest kompozytor Faustas Latėnas, autor muzyki także do wielu spektakli Eimuntasa Nekrošiusa.

3 Valstybinis Vilniaus mažasis teatras (Państwowy Wileński Teatr Mały) początkowo finansowo i administracyjnie nadal podlegał Akademickiemu Teatrowi Dramatycznemu. Zanim otrzymał własną siedzibę, swoje spek-
} 
Spektakl zaproszony na wiele festiwali, w tym do Toronto i Montrealu, stał się zapowiedzią teatralnej wiosny (Aleksaitè 2009: 59), która towarzyszyła powszechnej euforii związanej z nadchodzącymi zmianami politycznymi i upadkiem Związku Radzieckiego ${ }^{4}$.

Čia nebus mirties jest uważany za pierwszy postdramatyczny spektakl na Litwie (Balevičiūtė 2012: 75). Jego podstawy nie stanowił żaden gotowy tekst dramatyczny. Przedstawienie składało się z pojedynczych, luźno powiązanych ze sobą scen z przeszłości głównego bohatera - z okresu jego życia w powojennej Litwie. Reżyser, który we współpracy z Valdasem Kulkulasem napisał tekst, swobodnie mieszał czasy i postaci, zestawiając m.in. losy litewskiego poety z historią Martina Edena. Scenografię (autorstwa Virginiji Idzelytė) tworzył drewniany, pęknięty łuk z nierównomiernie przymocowanymi do niego żarówkami, za którym stała prosta ściana zbita z desek. Po lewej stronie widać było fragment wiejskiej chaty, po prawej betonowe schody i wejście do bloku. W „kalejdoskopie obrazów" - jak określiła strukturę tego przedstawienia Trinkūnaitè - ujawniał się bogaty i sugestywny portret czasów stalinowskich, przywołujący pamięć o bolesnej przeszłości. $\mathrm{Z}$ jednej strony był to polityczny manifest antykomunistyczny nowego zespołu Tuminasa, w pełni odzwierciedlający burzliwy nastrój tamtych dni, z drugiej zaś była to subtelna, oniryczna opowieść o poecie skrzywdzonym przez los, biednym i samotnym człowieku, który bardziej niż współczucia czy pocieszenia potrzebował bliskości.

„»Pobyć trochę razem《 i stan ten przekształcić w święto - jak pisała Ramuné Balevičiūte - to zarówno artystyczny, jak i nieartystyczny imperatyw teatru Rimasa Tuminasa, manifestacja wspólnoty na scenie i w życiu, wspólnego określania idealnego modelu recepcji spektaklu" (Balevičiūtè 2012: 200). Podobny postulat pojawił się w zrealizowanym dwa lata później Wiśniowym sadzie Antona Czechowa (1990), gdzie główny temat powrotu do rodzinnego domu doskonale wpisywał się w nastrój ogólnej radości wywołanej odzyskaniem przez Litwę niepodległości. Tuminas potraktował go jednak przewrotnie: dom Raniewskiej okazywał się starą i zniszczoną ruiną ze spróchniałym sufitem, przez który przebijał się róg potężnej drewnianej szafy, wiszący nad bohaterami niczym znak nadchodzącego rozpadu. Nic dziwnego, że Raniewska wcale nie cieszyła się ze swojego powrotu, zaś Duniaszy bardziej niż na związku z Jaszą zależało na wyjeździe do Paryża - Tuminas zdemaskował jej prawdziwe pragnienie $w$ scenie, $w$ której dziewczyna potajemnie zabierała wierzchołek przywiezionej z Francji kopii wieży Eiffla, stojącej z boku przez większą część spektaklu.

Bohaterowie Tuminasa często mówią o wyjeździe - jest to rodzaj marzenia o lepszym życiu, z dala od szarej codzienności. Ta podróż odbywa się zazwyczaj w czasie, jest skierowana ku przeszłości, ale zdarzają się spektakle, w których zostaje potraktowana dosłownie. Tak było w przypadku opartego na motywach powieści Grigorija Kanowicza spektaklu Nusišypsok mums, Viešpatie (Uśmiechnij się do nas, Panie) zrealizowanego w 1994 roku. Jego główny bohater to żydowski kamieniarz Efraim Dudak, który na wieść o tym, że jego syno-

takle pokazywał na Małej Scenie. Jego odłączeniu się sprzyjała jednak sytuacja w samym Teatrze Akademickim, którego artystyczny zespół składał się z ponad siedemdziesięciu aktorów. Ten problem rozwiązało odejście części z nich do Teatru Małego Tuminasa.

${ }^{4}$ Osłabienie Związku Radzieckiego w końcu lat 80. doprowadziło na Litwie do powstania Sajūdisu - nieformalnego ruchu społecznego (z Vytautasem Landsbergisem na czele) na rzecz przebudowy (pierestrojki). Organizacja w dużym stopniu przyczyniła się do podpisania 11 marca 1990 roku Aktu Przywrócenia Państwa Litewskiego. 
wi zagraża niebezpieczeństwo, wyrusza wraz z dwojgiem przyjaciół: Szmulem Senderem (Vytautas Grigolis) i Awnerem Rosenthalem (Gediminas Girdvainis) w podróż do Wilna. Ich wyprawa staje się wielką metaforą losu Efraima nie tylko jako ojca, ale również jako człowieka, jego miejsca w świecie i roli, jaką odgrywa w społeczeństwie. Podobnie jak w Wiśniowym sadzie czy zrealizowanym w 2006 roku w warszawskim Teatrze Studio Studze dwóch panów Goldoniego główny element scenografii Adomasa Jacovskisa ${ }^{5}$ stanowiła sterta walizek i kufrów - symbol podróży rozumianej zarówno jako powrót do rodzinnego domu, jak i wyprawy w poszukiwaniu lepszego miejsca na ziemi. Pojemność tej metafory była zresztą ogromna. Przy okazji Nusišypsok mums, Viešpatie Rasa Vasinauskaite pisała, że „zrealizowana teatralnymi środkami podróż Żydów stawała się kwintesencją wszystkich scenicznych działań, metaforą litewskich doświadczeń - podróży z peryferii do stolicy, z przeszłości do teraźniejszości, z bieżącego czasu przez meandry historii - do pamięci” (Vasinauskaitè 1994: 12).

Uśmiechnij się do nas, Panie okazało się ogromnym sukcesem: było pokazywane na całym świecie, zdobyło wiele nagród krajowych (w tym Šventojo Kristoforo statulèlè, czyli Statuetkę Świętego Krzysztofa przyznawaną co roku najbardziej zasłużonym mieszkańcom Wilna za osiągnięcia w różnych dziedzinach kultury i sztuki) oraz na międzynarodowych festiwalach teatralnych. Był to pierwszy spektakl Tuminasa zaproszony na Międzynarodowy Festiwal Teatralny „Kontakt” (1995), na którym Girdvainis otrzymał nagrodę aktorską za rolę Rosenthala.

Z kolei późniejszy o niemal dekadę Madagaskar Mariusa Ivaškevičiusa (2004) może być w całości potraktowany jako podróż do przeszłości, wspomnienie głównego bohatera. Jest nim geopolityk i utopista Kazys Pokštas (Ramūnas Cicènas), który marzy o przeniesieniu Litwy na tytułowy Madagaskar - miejsce gwarantujące spokój i szansę rozwoju. W ekspozycji spektaklu ubrany w płaszcz i kapelusz, z walizką w ręku Pokštas wchodzi tyłem do rodzinnego domu, tak jakby cofał się w czasie. Następująca po niej scena jego narodzin, a ściślej - rodzinnego porodu - jest całkowicie groteskowa: siedząca przy stole matka wydaje niemy okrzyk, a spod blatu wyłania się wykrzywiona w grymasie twarz Pokštasa ubranego w niemowlęcą czapeczkę. Kolejne epizody są budowane na zasadzie przywoływania scen z życia głównych bohaterów: Pokštasa lub poetki Salomèji Nèris (Gintarè Latvènaitė). Łączy je obecność drewnianej kołyski, która zmienia swoje znaczenie w poszczególnych epizodach: początkowo służy jako dziecięce łóżeczko, potem jako łódka, a na końcu staje się uniwersalnym symbolem podróży w poszukiwaniu Ziemi Obiecanej. Spektakl pokazywany na festiwalu „Kontakt” w 2005 roku zebrał kolejne wyróżnienia: II Nagrodę, Nagrodę im. Marka Okopińskiego dla najlepszego reżysera oraz Nagrodę „Gazety Wyborczej” dla najlepszej aktorki, którą otrzymałą Gintaré Latvènaitė za rolę Salomèi Nèris.

Tuminasowi sprzyjała dobra passa. W 1995 roku objął na jedną kadencję prowadzenie Teatru Akademickiego, który z czasem zmienił nazwę na Litewski Narodowy Teatr Dramatyczny ${ }^{6}$. W tym czasie na jego deskach wyreżyserował tylko trzy przedstawienia: Lituanicę litewskiego pisarza Sauliusa Šaltenisa, opowiadającą o historycznym locie przez Atlantyk dwóch litewskich pilotów Steponasa Dariusa i Stasysa Girenasa oraz dwie trage-

5 Nusišypsok mums, Viešpatie była pierwszym wspólnie zrealizowanym spektaklem Tuminasa i Jacovskisa, który wcześniej współpracował głównie z Eimuntasem Nekrošiusem w Teatrze Młodzieżowym (Jaunimo teatras). Od 1994 roku został głównym scenografem także Tuminasa.

6 Lietuvos nacionalinis dramos teatras - nazwa obowiązująca od 3 sierpnia 1998 roku. 
die: Króla Edypa Sofoklesa i Ryszarda III Williama Shakespeare’a. Pracował natomiast dużo za granicą: w Islandii, Szwecji, Rosji i Szkocji, gdzie wystawiał klasykę: dwukrotnie Don Juana Moliera oraz Trzy siostry Czechowa ${ }^{7}$. Teatr Mały grał w tym czasie stosunkowo niewiele, rzadko też dawał nowe premiery. Mimo sukcesów przedstawień takich jak Wiśniowy sad czy Uśmiechnij się do nas, Panie miasto będące już wówczas głównym organizatorem teatru rozważało jego zamknięcie. W odpowiedzi Tuminas wyreżyserował Maskaradę (1994) Michaiła Lermontowa, która (grana do dziś!) jest jednym z jego najpiękniejszych przedstawień. W 1997 roku zdobyła nie tylko Grand Prix „Kontaktu”, ale również Nagrodę Dziennikarzy. Wygrała wówczas z legendarnym Hamletem Nekrošiusa, który zajął drugie miejsce.

Maskarada jest $\mathrm{z}$ ducha antyromantycznym przedstawieniem przepełnionym atmosferą dziecięcej zabawy i grą $\mathrm{z}$ teatralnością, a jednocześnie - bolesnym, opowiadającym o ludzkiej samotności, tęsknocie za pięknem i miłością, o okrucieństwie świata. Scenografia Jacovskisa przedstawia ośnieżony park ${ }^{8}$, który stanowi wyraźnie wyznaczone miejsce dla nie tyle aktorskich działań, co gier postaci, jest swoistym placem zabaw, na którym będzie rozgrywać się akcja. Egmontas Jansonas twierdzi, że teatr Tuminasa „jest przede wszystkim Te a t r e m [podkr. - E. J.], to znaczy miejscem zabawy, gry, udawania" (Jansonas 1997: 67). Może to być zaśnieżone podwórko w Maskaradzie, złożony z mebli i walizek wóz w Uśmiechnij się do nas, Panie czy podest-pokój w domu sióstr Prozorow. W takim świecie wiele przedmiotów zostaje pozbawionych swojej podstawowej funkcji i - jak w dziecięcej zabawie - wykorzystanych w zupełnie nieoczekiwany sposób. Dlatego położona na bok szafa staje się koniem ciągnącym powóz (Uśmiechnij się do nas, Panie), a puchowe poduszki żołnierskimi hełmami (Trzy siostry). W Maskaradzie zabawa przedmiotami zyskuje dodatkowo metaforyczny wymiar: w serii komicznych scen jedna z postaci kolejno lepi bałwana, łowi karpia w przeręblu, mówi do portretu cara na banknocie - jest tak bardzo samotna, że szuka towarzystwa czegokolwiek, co pozwala do siebie mówić, ponieważ nikt nie chce jej wysłuchać.

W teatrze Tuminasa właściwie nie istnieją wyraźnie zarysowane konflikty dramatyczne. Rozpływają się one w poczuciu efemeryczności świata, przemijania i tęsknoty za tym, co nieosiągalne. W piękną zimową scenerię Maskarady reżyser wprowadza stylizowany na antyczną rzeźbę posąg kobiety. Kiedy w finale spektaklu na postumencie staje Nina (Adrija Čepaitė) ${ }^{9}$, wiadomo, że to ją uwiecznił Arbienin (Arvydas Dapšys) w parkowej figurze. Jego żony nie ma tak naprawdę już od dawna, a wszystko to, co widzieliśmy przed chwilą na scenie, okazuje się tylko bolesnym wspomnieniem.

Reżyser chętnie łączy różne gatunki i konwencje teatralne. Parodię i groteskę miesza z elementami teatru psychologicznego, tragizm z humorem, a komizm z nostalgią i liryzmem. Interesują go paradoksy: pozornie realistyczne sceny ukazuje jako absurdalne, a w absurdalnych szuka życiowej prawdy. Rozbija strukturę dramatów, wprowadzając na scenę szereg

\footnotetext{
7 Don Juan w Teatrze Narodowym Islandii w Reikjaviku i Vasateatern w Sztokholmie, obydwa w 1995 roku; Trzy siostry w Teatrze Narodowym Islandii w 1997 roku.

8 Zimowych obrazów pełno jest w Maskaradzie i Trzech siostrach, pojawiają się także w Mądremu biada Aleksandra Gribojedowa, zrealizowanym przez Tuminasa w 2007 roku w moskiewskim teatrze Sowriemiennik. Symbolem panującej zimy jest pośrednio zmora unosząca się nad sceną w Rewizorze, w której Ramune Balevičiūtè dopatrywała się słowiańskiej bogini zimy i śmierci Marzanny. Por. Balevičiūtè 2012: 126.

9 W pierwszej obsadzie. Obecnie gra tę rolę Indrè Patkauskaitė.
} 
nielogicznych i bezpośrednio niezwiązanych z akcją pantomimicznych obrazów. Śmiech, a właściwie subtelna ironia, jest dla niego sposobem na obnażenie absurdu ludzkiego istnienia. W Maskaradzie, podobnie jak w spektaklach opartych na dramatach Czechowa, jest także sposobem na przewartościowanie rosyjskiej tradycji teatralnej XIX wieku. Zdaniem Audronisa Liugi:

Tuminasowi udało się otworzyć dramat Lermontowa za pomocą innego niż romantyczny klucza. Wydaje się, że żywioł jego spektaklu łączy się z ludową (w najlepszym tego słowa znaczeniu) tradycją teatralną, której źródło kryje się nie w dziewiętnastowiecznym romantyzmie, a w folklorze i gatunku commedii dell'arte. To z niego powstaje żywioł zabawy spektaklu i najważniejsze jego motywy (Liuga 1997).

Najlepiej pokazuje to przykład postaci sługi granego przez Andriusa Žebrauskasa, której nie ma w tekście Lermontowa. Ubrany w stary płaszcz, ciepłą uszatkę i walonki, rozpoczyna spektakl swoją pantomimą. Ślizga się po śniegu i lepi z niego małą kulkę. Ten motyw, podobnie jak i sama obecność improwizowanych scen z udziałem Žebrauskasa, będzie się powtarzać przez cały spektakl. W zachowaniu bohatera widać nie tylko dziecięcą radość psotnika i pociąg do zabawy, ale również swego rodzaju wariację na temat Arlekina. Tuminas tego typu postaciom, które bardzo często powołuje do życia, przypisuje istotną rolę. Choć są nieme, w jakiś sposób, jak to ujął Wojciech Majcherek, „panują nad tym światem” (Majcherek 1997: 21). W Maskaradzie to właśnie ten sługa toczy śniegową kulę, która stopniowo rośnie, aby w finale zmiażdżyć kolejno bohaterów.

Błazenada i fatum są u Tuminasa właściwie nierozdzielne. W jednym z wywiadów mówil, że „w teatrze wysoka tragedia powinna się zmieścić w kilku minutach. Problem polega na tym, czym wypełnić pozostały czas [...]. Tragedia, dramat musi się zawrzeć w tych kilku minutach, a reszta to teatr, żonglowanie gatunkami, tragifarsą, komedią, czym się da” (Tuminas 1998). W zrealizowanym w 1998 roku pod szyldem Teatru Małego Królu Edypie, w scenografii złożonej z fragmentów kolumn i kapitelów rozrzuconych między gruzami najbardziej tragicznym momentom dramatu towarzyszyły akrobatyczne popisy choreutów ${ }^{10}$ oraz parodia gwiazdorskiego aktorstwa w wykonaniu Kapłana (Arūnas Sakalauskas). W centrum leżała przewrócona wieża obronna, pozornie do niczego już nieprzydatna, która w finale okazywała się niszczycielską siłą. Podobną rolę spełniały także m.in. wspomniane szafa w Wiśniowym sadzie czy kula śniegu w Maskaradzie. W Rewizorze z 2001 roku nad niemal pustą sceną przez cały czas unosiła się potężna konstrukcja pokryta materiałem i przypominająca z jednej strony ludową kukłę czy też mitologiczną zmorę, z drugiej - budynek cerkwi. W trakcie spektaklu zmieniała swoje położenie, czasem zatrzymując się w ukryciu, innym razem wirując nad sceną. Jej znaczenie ulegało nieustannym przeobrażeniom: od „radości społeczności pokazującej miasto urzędnikowi, który okazał się nie tak surowy, jak się spodziewano” po symbol „władzy zrodzonej z kłamstwa, przemocy i religijnej uzurpacji” (Drewniak 2001: 88). W finale spektaklu złowieszczo krążyła wokół przytulonej do słupa, zrozpaczonej córki Horodniczego.

10 W postaciach choreutów można było się również dopatrzeć podobieństwa do postaci z commedii dell'arte oraz klaunów z filmu Felliniego. Skojarzenie z włoskim reżyserem nie jest tu zresztą bezpodstawne - krytycy wielokrotnie nazywali Tuminasa „litewskim Fellinim", czemu sprzyjał nie tylko podobny sposób patrzenia na rzeczywistość, ale również zbieżna data urodzin. 
Rewizor w pewien sposób zamknął kolejny etap twórczości reżysera oparty na współpracy ze starszymi aktorami. Od tej pory pracował głównie z młodymi, kontynuując swoje poszukiwania w obrębie teatru zabawy. W 2002 roku zrealizował Czekając na Godota Samuela Becketta, w którym zajął się tematem metateatralności. Po raz pierwszy metateatralną ramę wykorzystał kilka lat wcześniej w Lituanice Sauliusa Šaltenisa (1996), kiedy to tragiczną historię lotu Dariusa i Girenasa opowiadał przez pryzmat amatorskiego przedstawienia wystawianego w czasie niemieckiej okupacji. W Czekajac na Godota miejsce akcji tworzyła nowa, będąca jeszcze w trakcie remontu scena przy Prospekcie Giedymina, która miała stać się siedzibą Teatru Małego. Ascetyczna scenografia Jacovskisa podkreślała autentyczną niegotowość przestrzeni, wykorzystując tym samym motyw „teatru w teatrze”. Estragon (Andrius Žebrauskas) i Vladimir (Arvydas Dapšys) to dwaj przyjaciele, którzy spotykali się głównie po to, aby razem spędzać czas. Oczekiwanie na Godota było dla nich sposobem na wspólne przeżywanie codzienności, pełne okazji do żartów i zabawy. Wszystko stawało się tu pretekstem do figli: ciasne buty Estragona, suche drzewo, marchewka i rzodkiewka. Farsową i pełną improwizacji tonację przedstawienia kontrapunktowała melancholijna muzyka Faustasa Latenasa, która wprowadzała element niepokoju do pozornie beztroskiej rzeczywistości.

Sofokles i Beckett, wcześniej także Brecht, Shakespeare, Lermontow i Czechow - decyzje repertuarowe reżysera o tak wyrazistej estetyce oraz zakresie interesujących go tematów mogą wydawać się niezrozumiałe. Łączy je jednak pojęcie absurdu rozumianego jako śmieszność, małość i bezsens ludzkiej egzystencji. To on jest właściwie głównym tematem całej teatralnej działalności Tuminasa. Sam definiował go w następujący sposób:

Katastrofizm wynika z silnego poczucia bezsensu, absurdu naszego istnienia. W naszym cywilizowanym życiu ciągle do czegoś dążymy. [...] Wiem, że nie da się tego zatrzymać, ale mam poczucie śmieszności tego wszystkiego, jakiegoś absurdu. Jedyne, co można zrobić, to pokazać, co się dzieje, próbować to nazwać. Trzeba powiedzieć, że to amoralne, tylko to można w tej sytuacji uczynić. Dlatego śmieję się (Tuminas 1998).

Choć reżyser rzadko sięga po dramaty litewskich autorów, nie rezygnuje z nich całkowicie. Dwukrotnie inscenizował teksty popularnego na Litwie dramatopisarza Mariusa Ivaškevičiusa: wspomniany już Madagaskar (2004) i Mistrza (2010). Ich bohaterami są historyczne postaci związane z życiem artystycznym i intelektualnym Litwy: Adam Mickiewicz, Andrzej Towiański, podróżnik i geograf Kazys Pakštas ${ }^{11}$, poetka Salomėja Nèris, poeta i dyplomata Oskar Miłosz, lotnicy Steponas Darius i Stasys Girėnas. Reżyser chętnie korzysta z powszechnie znanych i typowych dla kultury litewskiej znaków oraz symboli. Żongluje nimi, bawi się cytatami i skojarzeniami, nieustannie puszczając oko do widza. W Madagaskarze nieudany lot przez Atlantyk zainscenizował za pomocą zabawki i dobrze znanej Litwinom kulturowej kliszy: drewniany samolocik rozdzierał reprodukcję obrazu Las najsłynniejszego litewskiego malarza Mikalojusa Konstantinasa Čiurlionisa.

11 Ivaškevičius zmienił jego nazwisko na Pokštas, co w języku litewskim oznacza żart, figiel. 




Gintarẻ Latvènaitè (Salè, klęczy) i Valda Bičkutè (Milè) w Madagaskarze M. Ivaškevičiusa w reż. Rimasa Tuminasa

Fot. Wojtek Szabelski. Z archiwum Teatru im. W. Horzycy 
Niewątpliwie Tuminasowi znacznie bliższa jest dramaturgia rosyjska, szczególnie dramaty Antona Czechowa. Choć wystawiał je bardzo często, robił to głównie za granicą ${ }^{12}$. W Wilnie zrealizował zaledwie trzy spektakle, z których jednak każdy w pewnym sensie inaugurował nowy etap jego teatralnej działalności. Wiśniowy sad z 1990 roku był pierwszą oficjalną premierą Teatru Małego, Trzy siostry z 2005 otworzyły nową scenę przy Prospekcie Giedymina, a Mewa z 2009 rozpoczęła współpracę z nowym pokoleniem aktorów - absolwentów kursu Tuminasa ze szkoły teatralnej. We wszystkich trzech spektaklach reżyser powracał do źródeł teatru psychologicznego, nie rezygnując przy tym ze swoich skłonności do teatralnej i dziecięcej zabawy. Widział w nich bowiem sposób na przeciwstawienie się realistyczno-psychologicznej manierze aktorskiej opartej na przeżywaniu zgodnie z systemem Stanisławskiego. Zwrócił na to uwagę Tadeusz Kornaś:

Najbardziej zadziwiające jest u Tuminasa aktorstwo - dalekie od „pierieżywania” Stanisławskiego, ale równie dalekie od tradycji Brechta. [...] Zamiast odwzorowywania codziennych zachowań, aktorzy poddają dziwny ton - zawierający wręcz rytualny potencjał. Jakby poszukiwano gestów powszechnych, odnajdywanych w obrazach, niecodziennych zachowaniach. Nie jest to w żadnym wypadku celebrowanie, ale jednak niekiedy odnieść można wrażenie pewnej hieratyzacji gestu. W przedstawieniu Tuminasa tego rodzaju niepsychologiczne środki są materiałem głębokiej gry psychologicznej. Ów naddatek, którego nie odnaleźlibyśmy w „graniu zwykłego życia”, nadaje postaciom wieloznaczność i powoduje, że nie umiemy ich tak naprawdę rozgryźć (Kornaś 2005: 100)

Wielu protagonistów w teatrze Tuminasa to słabi, ufni i naiwni ludzie, którzy bywają złośliwi, kapryśni, popełniają błędy, przede wszystkim jednak podchodzą do życia z dziecięcą ciekawością. To romantycy, oderwani od rzeczywistości idealiści, którzy w swoich pragnieniach i dążeniach do osiągnięcia szczęścia pozostają zawsze samotni i niespełnieni. Taki jest chociażby Chlestakow, w którym łatwiej niż sprytnego młodzieńca można zobaczyć głodnego, zmarzniętego, nieco zagubionego chłopca. Wzbudza sympatię i pewnego rodzaju współczucie nawet wówczas, kiedy upija się w domu Horodniczego i dość obcesowo poczyna sobie z jego domownikami. Podobnie Kazys Pokštas w Madagaskarze: grający go Ramūnas Cicénas ani razu nie kpi z tego fantasty marzącego o przeniesieniu Litwy na Madagaskar, ale traktuje go z subtelną ironią.

W 2007 roku Tuminas został dyrektorem Państwowego Akademickiego Teatru im. Jewgienija Wachtangowa w Moskwie. Wystawia tam głównie rosyjską klasykę: Czechowa, Gogola, Puszkina. Wraca również do tytułów, które przyniosły mu rozgłos (Maskarada, Uśmiechnij się do nas, Panie). Dzisiaj rzadko pracuje w Wilnie, choć formalnie wciąż jest dyrektorem Teatru Małego. W ciągu ostatnich dziesięciu lat na jego deskach wyreżyserował zaledwie trzy przedstawienia (ostatnie, Minettiego Thomasa Bernharda, w 2015 roku), które eksploatując te same wątki i środki, nie powtórzyły wcześniejszych międzynarodowych sukcesów. Mimo to grane sporadycznie nieustannie przyciągają publiczność - wilnianie są ewidentnie bardzo przywiązani do jego teatru.

12 W Szwecji, Finlandii, Islandii, Szkocji, Rosji. 
"Ja tylko buduję dom, w którym ludzie chcą żyć. Interesujący, czasem straszny, ale przytulny, dobrze zaplanowany" (Tuminas 2006) - mówił Tuminas w jednym z wywiadów. „Ten dom, znajdujący się przy Prospekcie Giedymina, wciąż stoi otworem dla wszystkich, którzy zechcą do niego wejść”.

\section{Bibliografia}

Aleksaitė, Irena, Rasa Vasinauskaitė, Helmutas Šabasevičius (red.). 2009. Lietuviu teatro istorija. Ketvirtoji knyga 1980-1990. Vilnius: LKTI.

Aleksaitè, Irena 2009. „Valstybinis akademinis dramos teatras”.W: Irena Aleksaitė, Rasa Vasinauskaitè, Helmutas Šabasevičius (red.). Lietuvių teatro istorija. Ketvirtoji knyga 1980-1990. Vilnius: LKTI.

Balevičiūtè, Ramunè 2012. Rimas Tuminas: teatras, tikresnis už gyvenimą. Žaidimas Rimo Tumino teatre. Vilnius: Metodika.

Drewniak, Łukasz 2001. „Tuminas: Bardzo śmieszna tragedia”. Dialog 3.

Jansonas, Egmontas 1997. „Romantizmas: kalnai kelmuoti, herojai nuplikę, tik keli postamentai likę". Teatras 1.

Liuga, Audronis 1997. „Sniego nublokšti”. Krantai 1.

Kornaś, Tadeusz 2005. „Pieśni Syren”. Didaskalia 69.

Majcherek, Wojciech 1997. „Z notatnika festiwalowicza. (Kontakt'97)”. Teatr 7-8.

Trinkūnaitè, Šarūnè. „Rimas Tuminas: teatras, kuriame neprekaituojama”. http://www.mmcentras. lt/kulturos-istorija/kulturos-istorija/teatras/19801990-autorines-rezisuros-triumfas/ rimas-tuminas-teatras-kuriame-neprakaituojama/4509 [21.02.2017].

Tuminas, Rimas 1998. „Teatr jest pięknym sadem. Z Rimasem Tuminasem rozmawiają Malwina Głowacka, Katarzyna Osińska i Aleksandra Rembowska”. Teatr 4.

- 2006. „Bo teatr kocha się ze strachu. Z Rimasem Tuminasem rozmawia Joanna Derkaczew”. Gazeta Wyborcza 41.

Vasinauskaitè, Rasa 1994. „Ilga kelionè ị amžinybę ...”. Literatūra ir menas 19.11. 